\title{
The Effect of Productive Subject Competencies Against Industrial Work Practices
}

\author{
I Nyoman Suputra'; Lulu Nurul Istanti²; Adietya Putra Pratama ${ }^{3}$ \\ Educational Office Administration Program, State University of Malang \\ Email : lulu.nurul.fe@um.ac.id
}

\begin{abstract}
: the purpose of this study was to determine the suitability of students' productive learning competencies with the implementation of industrial work practices in SMK Muhammadiyah 5 Kepanjen, Malang.. This research used a descriptive qualitative approach. Data collection was obtained by conducting interview techniques, observation, and study documentation. The subjects of this study were the head of the industrial work practice program, the head of office management automation competency expertise, students of XI grade at SMK Muhammadiyah 5 Kepanjen, and the DUDI. The results of this study were (1) the process of implementing industrial work practices began with planning by schools, testing the productive ability of students, debriefing, placement, checking, and pickup, (2) evaluation of industrial work practices in SMK Muhammadiyah 5 Kepanjen was done by asking the opinions of all those who participated in industrial work practices, but it did not include DUDI in the evaluation activities, (3) the competency of office automation and governance in SMK Muhammadiyah 5 Kepanjen was already relevant to DUDI demands but there were several DUDI still unable to provide relevant jobs with competencies held by students in office automation and governance.
\end{abstract}

Keywords: suitability, competence, productive learning, industrial work practices

\section{INTRODUCTION}

Industrial Work Practices (Internship) are activities involving students to experience real work experience in the business world or the industrial world to increase students' skilled experience and readiness to get to the workforce (Tamm, 2018). The concept of industrial work practices is roughly the same as the activities of the Professional Placement (KPL) and Internship (PKL) carried out at the University, only industrial work practices are beneficial for students at the Vocational and MAK level. Industrial work practices in the international realm are commonly referred to On The Job Training (OJT). Research conducted by Valdez, et al. (2015: 109) "... OJT program of the university significantly contributes to the development of basic skills, thinking skills, personal qualities and competencies on resources, interpersonal, information, systems and technology needed by tourism graduates as perceived.." showed that the internship program significantly contributed to the development of basic skills, thinking skills, personal qualities and competence of resources, interpersonal, information, systems and technology needed by graduates (Gur, 2012).

Before carrying out practice, individuals should understand the basic theory first (Heijke et al., 2003). If students do not understand the basic theory in the practice of practice, it would harm the practice implementation (Berge, 2018). 


\section{METHOD}

This research used a descriptive qualitative approach. Data collection was obtained by conducting interview techniques, observation, and study documentation. The subjects of this study were the head of the industrial work practice program, the head of office management automation competency expertise, students of XI grade at SMK Muhammadiyah 5 Kepanjen, and the DUDI which consisted of the Ardirejo Village Office, Kepanjen Health Center, Pakisaji KUD, and STIKES Kepanjen.

\section{RESULT \& DISCUSSION}

Characteristics of the Implementation of Industrial Work Practices in Automation Competency and Office Management in SMK Muhammadiyah 5 Kepanjen

The planning stage of the implementation of industrial work practices at SMK Muhammadiyah 5 Kepanjen was, first, determining the objectives of the implementation of industrial work practices so that if the goals had been set then the school could have targets to be achieved so that the implementation of industrial work practices could provide the expected results. The purpose of industrial work practices according to the Directorate of Vocational Development (2018: 5) was to provide direct experience to students in working, develop their skills, instill a work ethic, and achieve graduate competency standards. Whereas the aim of implementing industrial work practices from SMK Muhammadiyah 5 Kepanjen was to prepare students to learn to work independently, work in a team and develop the potential of students according to their fields, students could find out how people work under their expertise program, students could apply the theories obtained at school to the workforce, and added experience and new knowledge about the workforce. After the objectives of the industrial work practices had been formulated, the head of the industrial work program planned the schedule for industrial work practices would be held regarding to the 2018/2019 educational calendar of SMK Muhammadiyah 5 Kepanjen.

Second was preparing human resources before implementing industrial work practices. Human resources in this case were students and teachers (Bakar, 2018). Before carrying out industrial work practices, several things could have been considered by students and teachers, which are the readiness of the material and the requirements for participating in industrial work practices in SMK Muhammadiyah 5 Kepanjen. According to Wena (1997: 23), although learning in SMK consisted of learning in class and industry, both could have been seen as something intact. This meant that learning in schools was no less important than learning practices in DUDI, so schools could also have paid attention to the theoretical needs of students (Munastiwi, 2015). Material needs in SMK Muhammadiyah 5 Kepanjen were provided by OTKP productive teachers from theory in the classroom and practice in the laboratory. The material provided was following the competency of office automation expertise and governance, which referred to the 2013 curriculum. In the curriculum structure of SMK Muhammadiyah 5 Kepanjen for office automation and office management programs, there were vocational competencies and compulsory subjects. To check the readiness of students in terms of the readiness of the material in SMK 5 
Kepanjen Muhammadiyah required students to pass several practice tests. Tests in automation and office management competencies included: typing with ten fingers, mastering Microsoft Word, and mastering Microsoft Excel. In this stage, the head of the industrial work program also analyzed the skills competencies of students who took part in industrial work practices to find out what skills competencies could be combined to be put together to DUDI.

The third stage was carrying out administrative preparations. Bartono (2005: 48) stated that "For this administrative preparation, the educational institution could have communicated with the hotel to obtain information regarding the sending of trainees. The information collected could have been sufficient and useful so that the street vendor program could be compiled effectively (Sin and Kim, 2018). These data included: (1) Hotel willingness to accept Trainees, (2) Cost requirements, (3) Allowable time (there were when the hotel was full of guests and there were also quiet times, where the hotel was short of activities. There could also be many Other trainees who practiced and had not finished with their street vendors. (4) The maximum number of participants allowed. (5) Problems with lodging, transport, certificates, uniforms, and others. "

Based on the results of data exposure and research findings, the administrative stage at SMK Muhammadiyah 5 Kepanjen began with the DUDI search process with the method that each competency chair was assigned to search for and analyze the possibility of DUDI that could meet the competency needs of students from each department. Then each head of expertise competence collected the list of DUDI to the industrial work committee. Furthermore, the industrial work committee through public relations contacted each of the DUDI to coordinate related to the willingness of the DUDI to work together, the necessary administrative requirements such as the documents needed, how the cooperation process, whether using costs or not and how certificates for students. If in the administrative coordination process the DUDI was willing to accept students to carry out industrial work practices, the school would submit a letter of cooperation containing the number of students needed by DUDI.

Fourth was carrying out technical preparation. Bartono (2005: 49) stated that participants in industrial work practices could have prepared themselves technically by filling in the registration form and paying off the registration, preparing passport photos, uniforms, notes, and others. Based on the findings, technical preparatory research conducted by SMK Muhammadiyah 5 Kepanjen was done as follows: preparing the required documents such as MoUs, cover letters, books on reports on industrial work practices, and dress code determination. For funding in industrial work practices programs was taken through contributions from students in the amount of 350 thousand rupiah/child.

Fifth was mental preparation. Bartono (2005: 50) stated that mental preparation was very important because during the industrial work practice participants would experience a variety of conditions and environments that might be very different from the situation in schools. If students already had a strong psychological readiness, students would feel more confident in facing challenges. Based on data exposure and findings of mental preparation research conducted at SMK Muhammadiyah 5 Kepanjen, it was conducted through debriefing/socialization activities. The debriefing was carried out by gathering 
students who would do industrial work practices at the school mosque then the students would listen to the material from the head of the industrial work practices program. The material given at the time of the debriefing was about ethics, attitudes, discipline of students during the implementation of industrial work practices in DUDI, and appeals to maintain the good name of schools in DUDI. This is following the opinion of Bartono (2005: 50) which stated that preparing mentally of students was the most important thing through a briefing that minimally covered the problems that would be encountered.

Based on the explanation, the planning of the implementation of industrial work practices of SMK Muhammadiyah 5 Kepanjen was largely following the Directorate of Vocational Development (2018: 19) which stated that the main steps that could have been taken in the preparation or planning stages of vocational practice as follows: (1) to compile work practice guidelines industry, (2) to select student competencies, (3) to prepare industrial work practice programs, (4) to determine DUDI that would work together, (5) to debrief the students, and (6) to determine the mentors. However, SMK Muhammadiyah 5 Kepanjen did not make an industrial work practice program. Whereas the preparation of industrial work practices programs was very important in the planning of industrial work practices (Mills and Fullagar, 2017). The Directorate of Vocational Development (2018: 22) explained that in the preparation stage of school industry work practices were required to contain a number of basic competencies that would be learned by students in DUDI so that the preparation of industrial work practices programs could minimize the mismatch between the competencies of students with the placement of DUDI. Research by Edi, et al (2017: 26) at SMK Negeri 5 Surakarta showed that the preparation of industrial work practices or curriculum synchronization programs could reduce the learning gap in schools with practical competencies in DUDI (Sermsuk et al., 2014).

The stage of organizing industrial work practices was carried out by the school with job analysis. Subekhi \& Jauhar (2012: 101) revealed that job analysis was written information about what work could have been done in an organization so that the goals of the organization could be achieved. Job analysis provided information about job descriptions, job specifications, and estimates of future expansion and simplification of work (Albrechtsen et al., 2019).

In organizing industrial work practices, job analysis was compiled by the head of the industrial work program as follows: (1) the principal was responsible and generally protecting the implementation and process of industrial work practices to run smoothly, (2) the head of the industrial work practice program was responsible conducting communications with parties related to the implementation of industrial work practices, compiling work programs, holding meetings with members, leading the debriefing of students, monitoring all activities regarding industrial work practices, (3) the secretary was in charge of preparing everything that was administrative required by students, preparing the administration required by the supervising teacher, making industrial work practice proposals, preparing and managing letters related to industrial work practices, and making attendance of industrial work practice students, (4) treasurer was in charge of financial records in the implementation of industrial work practices, (5) data and information processors served data processors and 
were responsible for the computerization of industrial work practices, and (6) members were assigned to being actively involved in industrial work practices, members consisted of teachers who were responsible for finding DUDI and becoming mentors of learners.

The stage of organizing industrial work practices carried out by SMK Muhammadiyah 5 Kepanjen was the process of handing students to DUDI, students began to work, the monitoring process, and the withdrawal stage when industrial work practices are finished. After the industry confirms the willingness to accept students to carry out industrial work practices and has entered into an MoU with the school, the school will prepare students who will carry out industrial work practices. Submission of students to DUDI is accompanied by a supervising teacher. During the process of handing over students to meet with a supervisor from DUDI and explained of the distribution of tasks while in DUDI.

During industrial work practice activities, in addition to relying on the supervising teacher, the school done monitoring activities to find out the activities of students in DUDI and the problems that students could have faced while working in DUDI. Monitoring activities were carried out three times during the implementation of industrial work practices on Sundays at SMK Muhammadiyah 5 Kepanjen.

The Directorate of Vocational Development (2018: 16) stated that there were 3 (three) patterns of the implementation of industrial work practices, namely daily patterns, weekly patterns, and monthly patterns (block system). Based on the findings of the research data, the implementation of industrial work practices in SMK Muhammadiyah 5 Kepanjen used a monthly pattern. The Directorate of Vocational Development (2018: 18) suggested that the monthly pattern was done by distributing students to follow industrial work practices in DUDI for 6-10 months. However, at SMK Muhammadiyah 5 Kepanjen, industrial work practices were only held for 3 (three) months, from January 8 to April 8, 2019.

\section{Evaluation of the Implementation of Industrial Work Practices in SMK Muhammadiyah 5 Kepanjen}

Based on the results of data exposure and research findings, it showed that the competency assessment of students was done by DUDI institutions following the assessment guidelines given by SMK Muhammadiyah 5 Kepanjen. Assessment was in the form of general assessment and vocational assessment. The general assessment aspect contained the concepts that had been given by schools to DUDI institutions which consisted of an assessment of students' attitudes in implementing industrial work practices. Assessment of covering attitudes: time discipline, willingness to work, quality of work, initiative and creative, cooperation, responsibility, behavior, and cleanliness. Whereas the vocational assessment of industrial work practices was performance evaluation. Sudaryono (2012: 74) stated that performance appraisal was an assessment carried out by observing students' activities in doing something. Performance appraisal was used to assess the achievement of competencies that required students to do certain tasks (Sella, 2014). This was consistent with the opinion of Sudjana (2014: 57) which stated that the purpose of the assessment of the teaching and learning process was more emphasized on the improvement and optimization of teaching and learning 
activities themselves. Sudjana (2014: 57) added that one of the dimensions of the assessment of learning processes was the effectiveness and relevance of teaching materials. But in SMK Muhammadiyah 5 Kepanjen, vocational competency assessment was not included in the assessment guidelines. Whereas if schools included vocational assessment guidelines, DUDI could use them as guidelines in providing work to students so that the relevance of the vocational competencies of students could be more guaranteed. In the assessment activities of SMK Muhammadiyah 5 Kepanjen, they only used the value of the DUDI institution as a reference in the success of the industrial work practices program, so if the students of industrial work practice on average got good grades, the implementation of the industrial work practices program was considered to be going well.

Based on the results of the study, an evaluation of the implementation of industrial work practices was carried out by gathering students who had already done industrial work practices and being asked for opinions on experiences in implementing industrial work practices in their respective DUDI, with the aim that the school could find out the shortcomings or problems faced by students during industrial work practices, so that the evaluation could be used as a guideline for implementing future industrial work practices.

\section{Suitability of Productive Subject Competencies Learned by Students at Schools with Work Demands in Industrial Work Practices at SMK Muhammadiyah 5 Kepanjen}

Vocational High School Education (SMK) aims to create graduates who have expertise, skills, and become competent human beings in their fields according to the needs of DUDI. Along with the development of today, the demands of DUDI are increasingly complex. If we want to succeed in competition, then the educational world must be able to keep up with the times without having to leave the cultural heritage that we have. This means that schools in developing curriculum must continue to review and adjust their curriculum so that they can follow the demands of the industrial world.

Industrial Work Practices is an effort of SMKs to create graduates who have competitiveness in the workforce. Through the application of industrial work practices as a form of dual system education is expected to create a good relationship between the school and DUDI to realize the objectives of industrial work practices that produce graduates with expertise competencies that are following the needs of the workforce. Therefore the competency of the learners' expertise with the work done during industrial work practices must be appropriate or relevant.

Preparation of industrial work practices of SMK Muhammadiyah 5 Kepanjen began with preparing provisions in the form of theories to be given to students. Wena (1997: 27) stated that material in the industry was more emphasized on work practices but was related to theories learned in schools. Therefore, SMK Muhammadiyah 5 Kepanjen prepared material for its students based on the needs of the industry.

After getting the theories in learning in the class, next OTKP students had to take several tests in the form of practice held by the Vocational School to find out how well the students' understanding in applying the theories that had been 
taught. The test was related to office activities using the Microsoft Word application, Microsoft Excel, and 10-finger typing skills. Students who passed the test could register to participate in industrial work practices, while students whose grades were less could not participate in industrial work practices.

Based on the results of interviews with the head of the industrial work practice program, in the search for DUDI the head of industrial work practice contacted the DUDI who collaborated with SMK Muhammadiyah 5 Kepanjen in the previous school year. If the number of DUDI was not enough to meet the needs of students, the head of industrial work practices looked for additional DUDI to meet it. For administrative needs, SMKs submitted a letter of application for cooperation with DUDI, if DUDI had allowed SMK students to carry out industrial work practices, then the SMK provided a Memorandum of Understanding (MoU) containing cooperation agreement and the number of students needed by DUDI.

During participating in industrial work practices, students got a daily journal report book. In addition to containing journals that had to be filled with students' activities while in DUDI, the book also contained students' identities, letters of ability to follow industrial work practices and parental consent, attendance lists of students of industrial work practices, recapitulation of student values, and instructions assessment of participants in industrial work practices.

Research data on the relevance aspects of productive subjects with the implementation of industrial work practices in the Ardirejo Village Office, Kepanjen STIKES, KUD Pakisaji, and Kepanjen Health Center were found that students who done industrial work practices in the village office, STIKES, and health center got suitable jobs with competency in office automation and governance, which was filing letters, picking up phone and making documents. But students who done industrial work practices in KUD Pakisaji did not get following office automation and governance competencies. The students were assigned to work on the sales, purchase, and various accounting related work.

Based on the findings of the research data, the supervisor from KUD did not know well the competency of the students' expertise who done industrial work practices in that place, causing misunderstanding in assigning tasks to students. The head of the OTKP expertise competency and the head of the industrial work program explained that if DUDI was found to provide assignments that were not following the students' competency needs, the students would be withdrawn and transferred to other DUDI. However in several times the monitoring activities of the head of the industrial work program had not found students who claimed to get jobs that were not following the needs of their competencies. Here the important role of the supervising teacher was very necessary, the supervising teacher had to understand the job needs of the mentored students because the teacher knew more and understood the material that students had to learn. Teacher expertise relevant to the student's expertise program was expected to support the mentoring process to be more optimal. However, based on the research findings, it was found that there was no relevance between the competence of the supervising teacher and the students he supervised.

In KUD Pakisaji, the supervising teacher for the students of office automation and governance was a teacher from the accounting expertise program. Students of industrial work practices in KUD Pakisaji explained that the 
supervising teacher was difficult to contact and never asked about the relevance of the competencies learned by students to the work they got. This phenomenon was following the opinion of Wena (1997: 35) which stated that the failure of industrial work practices so far was largely due to students did not get adequate guidance in the industry. Therefore in the implementation of industrial work practices, the supervising teacher should have been someone who understood, cared, and was responsive to the problems contained in DUDI so that if there was a problem experienced by the students, the supervising teacher could become a facility for students to convey their difficulties.

Based on research findings industrial work practices affected soft skills of the students in SMK 5 Muhammadiyah Kepanjen. Soft skills included communication skills, critical thinking, and problem-solving that had experienced by the students after doing industrial work practices. As stated by the head of the OTKP expertise competency that after the implementation of industrial work practice, the students became more communicative and easier to absorb every lesson given by the teacher. This improvement could be obtained by several methods, as follows: (1) through affective learning, (2) extracurricular activities, and (3) through industrial work practices. Following a research by Andayani (2016: 753) showed there was an influence of the implementation of industrial work practices on students' skills. The implementation of industrial work practices contributed significantly to soft skills such as: honesty, discipline, commitment, communication, motivation, confidence, and creativity for students. This statement was supported the research done by Iyer \& Dave (2015: 156) which showed that the system of industrial involvement in education in Germany could educate the skills and attitudes of students based on the demands of the workforce.

\section{CONCLUSION}

The process of implementing industrial work practices began with planning by the school, testing the productive ability of students, briefing, placement, checking, and pickup. Evaluation of industrial work practices in SMK Muhammadiyah 5 Kepanjen was done by soliciting opinions from all parties participating in industrial work practices but did not include DUDI in the evaluation activities. The competency of office automation and governance in SMK Muhammadiyah 5 Kepanjen had been already relevant to the demands of DUDI but DUDI was still unable to provide jobs that were relevant to the competencies owned by office automation and office governance students. Furthermore, SMK Muhammadiyah 5 Kepanjen needs to further improve coordination with DUDI about the students' competency needs. Before carrying out industrial work practices, an industry feasibility evaluation and competency synchronization could be held with the DUDI to equalize perspectives on the implementation of industrial work practices. Coordination between the supervising teacher and the DUDI so it could be improved and supervision could be done more comprehensively, it was not only about the discipline of students, but also what work was done by students in DUDI also needed to be considered and if there were nonconformities with competency needs, it could be immediately coordinated with industrial work committee so it could be immediately followed up. In the monitoring activities held by the 
industrial work committee, written could be added to facilitate some students who lacked confidence in expressing their opinions in front of many people.

\section{REFERENCES}

Albrechtsen, E., Solberg, I., Svensli, E., 2019. The application and benefits of job safety analysis. Saf. Sci. 113, 425-437. https://doi.org/10.1016/j.ssci.2018.12.007

Andayani, E. 2016. Analisis Praktik Kerja Industri Terhadap Penguasaan Skill Siswa dalam Mengahadapi Dunia Kerja di SMK NU Bululawang Malang. Jurnal Inspirasi Pendidikan, 6(1), 744-754. Dari http://ejournal.uni kama.ac.id/index.phpn/jrnspirasi/ article/download/1079/839.

Bakar, R., 2018. The influence of professional teachers on Padang vocational school students' achievement. Kasetsart J. Soc. Sci. 39, 67-72. https://doi.org/10.1016/j.kjss.2017.12.017

Bartono, P.H. 2005. Hotel Training Yang Efektif. Yogyakarta: ANDI OFFSET.

Berge, W. van den, 2018. Bad start, bad match? The early career effects of graduating in a recession for vocational and academic graduates. Labour Econ., European Association of Labour Economists 29th annual conference, St.Gallen, Switzerland, 21-23 September 2017 53, 75-96. https://doi.org/10.1016/j.labeco.2018.05.011

Direktorat Pembinaan Sekolah Menengah Kejuruan. 2018. Pedoman Praktik Kerja Lapangan (PKL) Peserta Didik SMK. Jakarta: Depdikbud.

Gur, N., 2012. Government ownership of banks, job creation opportunities and employment growth. Econ. Lett. 117, 509-512. https://doi.org/10.1016/j.econlet.2012.06.039

Heijke, H., Meng, C., Ris, C., 2003. Fitting to the job: the role of generic and vocational competencies in adjustment and performance. Labour Econ., European Association of Labour Economists, 14th Annual Conference, 2002 10, 215-229. https://doi.org/10.1016/S0927-5371(03)00013-7

Mills, M.J., Fullagar, C.J., 2017. Engagement within occupational trainees: Individual difference predictors and commitment outcome. J. Vocat. Behav. 98, 35-45. https://doi.org/10.1016/j.jvb.2016.09.004

Munastiwi, E., 2015. The Management Model of Vocational Education Quality Assurance Using 'Holistic Skills Education (Holsked).' Procedia - Soc. Behav. Sci., The 4th World Congress on Technical Vocational Education and Training (4thWoCTVET), 5-6 December 2014, Universiti Tun Hussein Onn Malaysia, MALAYSIA 204, 218-230. https://doi.org/10.1016/j.sbspro.2015.08.144

Sella, L., 2014. Enhancing Vocational Training Effectiveness Through Active Labour Market Policies. Procedia - Soc. Behav. Sci., 4th World Conference on Learning Teaching and Educational Leadership (WCLTA-2013) 141, 11401144. https://doi.org/10.1016/j.sbspro.2014.05.192

Sermsuk, S., Chianchana, C., Stirayakorn, P., 2014. A Study of Model of Vocational Curriculum Development Under Vocational Education Commission Using Cross-impact Analysis. Procedia - Soc. Behav. Sci. 116, 1896-1901. https://doi.org/10.1016/j.sbspro.2014.01.491 
Sin, S.-C.J., Kim, K.-S., 2018. How Are We the Same or Different: Information Needs and Barriers of Domestic and International Students. J. Acad. Librariansh. 44, 712-723. https://doi.org/10.1016/j.acalib.2018.10.005

Subekhi, A. \& Jauhar, M. 2012. Pengantar Manajemen Sumber Daya Manusia (MSDM). Jakarta: Prestasi Pustaka

Sudaryono. 2012. Dasar-Dasar Evaluasi Pembelajaran. Yogyakarta: Graha Ilmu.

Sudjana, N. 2014. Penilaian Hasil Proses Belajar Mengejar. Bandung: PT Remaja Rosdakarya.

Tamm, M., 2018. Training and changes in job Tasks. Econ. Educ. Rev. 67, 137-147. https://doi.org/10.1016/j.econedurev.2018.09.007

Undang-Undang Dasar Republik Indonesia Tahun 1945. Pom (online), (jdih.pom.go.id/uud1945.pdf), diakses 21 November 2018.

Undang-Undang RI No. 20 Tahun 2003 tentang Sistem Pendidikan Nasional. Jaringan Dokumentasi dan Informasi Hukum Badan Pemeriksa Keuangan Republik Indonesia. Bpk (online), (www.jdih.bpk.go.id), diakses 23 November 2018.

Universitas Negeri Malang. 2017. Pedoman Penulisan Karya Ilmiah: Skripsi, Tesis, Disertasi, Artikel, Makalah, Tugas Akhir, Laporan Penelitian. Edisi Keenam. Malang: Universitas Negeri Malang.

Valdez. 2015. Contributions of On-the-Job Training Program to the Skills, Personal Qualities, and Competencies of Tourism Graduates. Asia Pacific Journal of Multidisciplinary Research, 3(4), 102-110. Dari https://www. researchgate.net/publication/288807944.

Wena, M. 1997. Pendidikan Kejuruan Sistem Ganda. Malang: Institut Keguruan Ilmu Pendidikan Malang. 